\title{
The chemokine CXCLI 3 is a key regulator of $B$ cell recruitment to the cerebrospinal fluid in acute Lyme neuroborreliosis
} Tobias A Rupprecht* ${ }^{* 1}$, Andreas Plate ${ }^{\dagger 1}$, Michaela Adam², Manfed Wick², Stefan Kastenbauer ${ }^{1}$, Caroline Schmidt ${ }^{1}$, Matthias Klein ${ }^{1}$, HansWalter Pfister ${ }^{1}$ and Uwe Koedel ${ }^{1}$

Address: ${ }^{1}$ Department of Neurology, Ludwig-Maximilians University, Marchioninistr. 15, 81377 Munich, Germany and ${ }^{2}$ Department of Clinical Chemistry, Ludwig-Maximilians University, Marchioninistr. 15, 81377 Munich, Germany

Email: Tobias A Rupprecht* - tobias.rupprecht@amperkliniken.de; Andreas Plate - andreas.plate@gmx.com; Michaela Adam - michaela.adam@med.uni-muenchen.de; Manfed Wick - manfred.wick@med.uni-muenchen.de; Stefan Kastenbauer - praxis@kastenbauer.de; Caroline Schmidt - caroline.schmidt@med.uni-muenchen.de; Matthias Klein - matthias.klein@med.uni-muenchen.de; Hans-Walter Pfister - hans-walter.pfister@med.uni-muenchen.de; Uwe Koedel - uwe.koedel@med.uni-muenchen.de

* Corresponding author †Equal contributors

Published: 30 December 2009

Journal of Neuroinflammation 2009, 6:42 doi:10.1186/1742-2094-6-42
Received: 28 October 2009

Accepted: 30 December 2009

This article is available from: http://www.jneuroinflammation.com/content/6/1/42

(C) 2009 Rupprecht et al; licensee BioMed Central Ltd.

This is an Open Access article distributed under the terms of the Creative Commons Attribution License (http://creativecommons.org/licenses/by/2.0), which permits unrestricted use, distribution, and reproduction in any medium, provided the original work is properly cited.

\begin{abstract}
Background: The chemokine CXCLI 3 is known to dictate homing and motility of B cells in lymphoid tissue and has been implicated in the formation of ectopic lymphoid tissue in chronic inflammation. Whether it influences $B$ cell trafficking during acute infection, is largely unclear. In previous studies, we showed that (I) CXCLI 3 levels are markedly increased in the B cell-rich cerebrospinal fluid (CSF) of patients with acute Lyme neuroborreliosis (LNB), and (II) CXCLI3 is released by monocytes upon recognition of borrelial outer surface proteins by Tolllike receptor 2. Here, we assessed the role of $C X C L I 3$ - in comparison to other chemokines - in the recruitment of $B$ cells to the CSF of patients with acute LNB.

Methods: Measurement of chemokines was done by ELISA. B cells were isolated from whole blood using magnetic cell separation (MACS). For migration experiments, a modified Boyden chamber assay was used and the migrated $B$ cells were further analysed by FACS. The migration was inhibited either by preincubation of the CSF samples with neutralizing antibodies, heating to $60^{\circ} \mathrm{C}$, removal of proteins $>3 \mathrm{kDa}$, or by pre-treatment of the $\mathrm{B}$ cells with pertussis toxin. The principal statistical tests used were one-way analysis of variance and Bonferroni test (chemokine measurements) as well as paired Student's t-test (migration experiments).

Results: Measurements of chemokine levels revealed an increase in three of the four known major $B$ cell chemoattractants CXCLI3, CCLI9 and CXCLI2 in LNB CSF. The CXCLI3 CSF:serum ratio, as a measure of the chemotactic gradient, was substantially higher than that of CCLI9 and CXCLI2. Moreover, the chemotactic activity of LNB CSF was reduced up to $56 \%$ after preincubation with a neutralizing CXCLI3 antibody, while combined preincubation with antibodies against CXCLI3, CCLI9, and CXCLI2 did not lead to further reduction. Since treatment with pertussis toxin, heating to $60^{\circ} \mathrm{C}$, and removal of proteins $>3 \mathrm{kDa}$ abrogated the chemotactic activity, further not yet identified chemokines seem to be involved in $B$ cell recruitment to LNB CSF.
\end{abstract}

Conclusion: Combined, our study suggests a key role of $\mathrm{CXCLI} 3$ in $\mathrm{B}$ cell migration to sites of infection as shown here for the CSF of LNB patients. 


\section{Background}

The field of function of CXCL13 has been constantly growing since its discovery in 1998 [1]. Initially, the essential role of CXCL13 was seen in the establishment and maintenance of lymphoid tissue microarchitecture [2]. Accordingly, CXCL13 deficient mice fail to develop lymph nodes [3], and B-cell homing to lymph node follicles requires CXCL13 and its exclusive receptor CXCR5 [4]. Some years later, evidence for a role in the formation of ectopic lymphoid tissue in chronic inflammation such as multiple sclerosis or rheumatoid arthritis was also found $[5,6]$. Finally, the detection of CXCL13 expression in Helicobacter pylori gastritis [7], pulmonary tuberculosis [8] or Bartonella henselae infection [9] suggested a role of this chemokine in chronic bacterial infections as well. Its influence on leucocyte migration to the site of infection, however, has not been evaluated so far.

Recently, we and others observed a strong up-regulation of CXCL13 expression in an acute bacterial infection, in Lyme neuroborreliosis (LNB) $[10,11]$. In LNB, the spirochete Borrelia burgdorferi (B.b.) invades the cerebrospinal fluid (CSF) [12]. The host immune system reacts to the invading spirochetes with a local inflammation, leading to an intrathecal accumulation of leucocytes. A hallmark of this CSF-pleocytosis in LNB is the accumulation of activated $B$ cells and plasma cells. The percentage of $B$ cells in the CSF of LNB patients reaches up to $80 \%$, clearly exceeding other CNS infections [13]. B cells show a substantial migration only to very few chemokines, namely, CCL19, CCL21, CXCL12, and CXCL13 [14].

In previous studies, we measured high concentrations of CXCL13 in the CSF of patients with LNB, even before the intrathecal production of B.b.-specific antibodies has started $[10,15]$. Cell culture experiments have shown, that PBMC produce CXCL13 in response to an incubation with B.b. through the interaction of the TLR2 receptor of the innate immune system with spirochete outer surface proteins [16]. This in vitro study is further supported by findings in the rhesus monkey model of LNB, where the CXCL13 expression at the spinal nerve roots correlated with the spirochete load and resident immune cells have been identified as source of this chemokine $[11,17]$. Based on these data, we speculated that in vivo, the high intrathecal concentration of CXCL13 in LNB patients directs the $\mathrm{B}$ cells to the CSF, leading to the observed $\mathrm{B}$ cell enriched CSF pleocytosis [12].

To further assess the role of CXCL13 for the $\mathrm{B}$ cell rich infiltrate in the CSF of LNB patients, we (1) examined the chemotactic activity of CSF samples from patients with LNB on human B cells, compared with that of patients with a non-inflammatory CNS diseases (NIND), and neurosyphilis (NS) as another spirochete CNS disease in a chemotaxis assay, (2) determined the concentrations of CXCL13 and other B cell attracting chemokines in CSF/ serum pairs of the three patient groups, and (3) tried to elucidate the contribution of these chemokines to the chemotactic activity of LNB by using specific neutralizing antibodies.

\section{Methods \\ B-cell isolation and stimulation}

Human peripheral blood mononuclear cells were extracted from venous blood samples from a healthy male donor using ficoll gradient centrifugation. Subsequent untouched B cells were isolated by Midi Macs System ${ }^{\circledast}$ (Miltenyi Biotec, Bergisch-Gladbach, Germany). The purity of the (CD19+) B cells, examined repetitively before and during the experiments by a FACS analysis, was always higher than $98.4 \%$. More than $95 \%$ of isolated cells were shown by the Trypan blue exclusion test to be viable. In order to stimulate the B cells to increase their migratory ability, they were incubated for 16 hours at $37^{\circ} \mathrm{C}$ and $5 \% \mathrm{CO}_{2}$ in RPMI 1640 medium supplemented with $10 \% \mathrm{FCS}, 100$ units penicillin and $100 \mu \mathrm{g}$ streptomycin/ml, $20 \mathrm{ng} / \mathrm{ml} \mathrm{IL4}$ and $1 \mu \mathrm{g} / \mathrm{ml}$ CD40L according to [14]. Thereafter, the cells were pelleted again and diluted to a working concentration of $2.6 \times 10^{\wedge} 6$ cells $/ \mathrm{ml}$ for the migration assays and $2.1 \times 10^{\wedge} 6$ cells $/ \mathrm{ml}$ for the inhibition assays.

\section{CSFlblood samples}

Blood was drawn and lumbar puncture was performed for diagnostic purposes after the patient's informed consent was obtained. All samples were frozen at $-30^{\circ} \mathrm{C}$. Paired CSF and blood samples were obtained from the following groups:

(i) 14 patients ( 9 males) with non-inflammatory CNS disease (NIND). The mean cell count was 1.8 [0.3-4.7] cells/ $\mu \mathrm{l}$, and the mean CSF/serum albumin ratio was 8.7 [3.3$31.0]$. The mean age was $64.7[48-74]$ years. Three of these patients suffered from chronic pain, two others had an epileptic seizure, and the further patients were diagnosed amyotrophic lateral sclerosis, vascular compression of the brain stem, Parkinson's disease, transverse myelitis, Guillain-Barré syndrome, multiple sclerosis, herniated vertebral disc, somatoform disorder or progressive ataxia.

(ii) 18 patients ( 11 males) with acute (duration of symptoms $<6$ months) Lyme neuroborreliosis (LNB) before initiation of therapy. The mean cell count was 146 [1-600] cells $/ \mu \mathrm{l}$ (for details, please refer to table 1 ), the mean CSF/ serum albumin ratio was 26.0 [3.9-43.9]. The mean age was 57.8 [15-72] years. The diagnosis of LNB was based on the following criteria: 1) typical clinical picture (e.g. meningoradiculitis, cranial neuritis or meningitis) 2) lymphocytic CSF pleocytosis, and 3) increased intrathecal 
Table I: Clinical data and basic CSF parameters of the LNB patients

\begin{tabular}{|c|c|c|c|c|c|c|c|}
\hline Pat. Nr. & $\begin{array}{c}\text { Gender } \\
\mathbf{f} / \mathbf{m}\end{array}$ & $\begin{array}{c}\text { Age } \\
\text { [y] }\end{array}$ & Clinical syndrome & $\begin{array}{c}\text { Cell count } \\
{[/ I]}\end{array}$ & $\begin{array}{c}\text { Plasma cells } \\
{[\%]}\end{array}$ & Albumin quotient' & Antibody index ${ }^{2}$ \\
\hline I & $f$ & 69 & BS & 53 & 15 & 43.9 & 1.7 \\
\hline 2 & $\mathrm{~m}$ & 15 & CNP, M & 600 & 0 & 5.4 & 4 \\
\hline 3 & $f$ & 70 & BS & 90 & 0 & 4.83 & n.d. ${ }^{+}$ \\
\hline 4 & $\mathrm{~m}$ & 62 & BS, CNP & 246 & 16 & 39.7 & 7.3 \\
\hline 5 & $f$ & 69 & BS & 109 & 5 & 15.8 & 13.3 \\
\hline 6 & $f$ & 61 & BS & 217 & I & 37.9 & 40.7 \\
\hline 7 & $\mathrm{~m}$ & 66 & $\mathrm{BS}, \mathrm{CNP}$ & 16 & 0 & 8.9 & $<1.5^{\#}$ \\
\hline 8 & $\mathrm{~m}$ & 67 & BS, M & 52 & 20 & 10.3 & 34 \\
\hline 9 & $\mathrm{~m}$ & 61 & BS & $I^{*}$ & 8 & 30.3 & 10.9 \\
\hline 10 & $\mathrm{~m}$ & 72 & CNP & 166 & 3 & 21.6 & 62.7 \\
\hline II & $\mathrm{m}$ & 59 & BS & 100 & 0 & 23.4 & 2.8 \\
\hline 12 & $\mathrm{~m}$ & 38 & $M$ & 117 & 11 & 26 & 168 \\
\hline 13 & $\mathrm{~m}$ & 55 & BS, CNP & 368 & n.d. & 19.1 & 38.6 \\
\hline 14 & $\mathrm{~m}$ & 50 & CNP & 12 & 0 & 4.5 & 7.7 \\
\hline 15 & $f$ & 46 & BS & 14 & 0 & 3.9 & 1.8 \\
\hline 16 & $\mathrm{~m}$ & 59 & BS & 30 & 0 & 13.2 & 2.5 \\
\hline 17 & $f$ & 59 & BS & 255 & 5 & 33.2 & 17.8 \\
\hline 18 & $f$ & 62 & CNP, M & 180 & I & 10.5 & 4.3 \\
\hline
\end{tabular}

BS: Bannwarth's syndrome (meningopolyradiculitis), CNP: Cerebral nerve palsy (Cranial neuritis), M: Meningitis. 'CSF/serum albumin quotient, 2 B.b.-specific antibody index. * = cell count at follow up lumbar puncture (8 days later) showed 70 leucocytes/ $\mu$ and an increasing antibody index (27.5). ${ }^{+}$antibody index initially not done, but on repeated lumbar puncture 13 days later, the CSF showed an B.b.-specific antibody index of 9.34 (and cell count of $102 / \mu \mathrm{l}$ ). ${ }^{\#}$ antibody index at follow up 4 days later 2.1 , and 12 days later 4.8 (and cell count of 13 , and I7, respectively).

B.b.-specific antibody production. Detailed data concerning basic CSF findings as well as the B.b.-specific antibody index and the percentage of plasma cells are given in table 1.

(iii) 14 patients (13 males) with neurosyphilis (NS). The mean cell count was 17.4 [5-45] cells/ $\mu$ l and the mean $\mathrm{CSF} /$ serum albumin ratio was 5.9 [3.2-12.5]. The mean age was 31.8 [19-48] years. The diagnosis was based on serological proof of a syphilitic infection (positive Treponema particle agglutination and fluorescent treponemal antibody absorbed tests) and an elevated CSF white blood cell count according to the criteria described by
Marra et al. [18]. All patients with syphilis were in the second stage of disease (secondary syphilis) and negative for the human immunodeficiency virus (HIV).

\section{Migration assay}

The migration assay was performed in a disposable 96well system (ChemoTx, Neuroprobe) with polycarbonate membrane filters ( $5 \mu \mathrm{m}$ pore). $30 \mu \mathrm{l}$ of the CSF samples were added to the lower chamber and $50 \mu \mathrm{l}$ B cell solution was added onto the membrane. The chamber was incubated for $1 \mathrm{~h}$ at $37^{\circ}$ in humidified air with $5 \% \mathrm{CO}_{2}$. After incubation, the migrated cells in the lower chamber were counted in a Fuchs-Rosenthal-chamber. 
For better comparison of the results from different experiments, a migration index was calculated. We used medium as negative control value and $500 \mathrm{ng} / \mathrm{ml}$ rhCXCL13 (R\&D Systems, Minneapolis, MN, USA) as a positive control.

$M I=(($ sample result - negative control $) /($ positive control - negative control $)) \times 100$ The results are presented in per cent. A MI of 100\% implicates, that the sample had the same chemotactic effect as 500 ng rhCXCL13.

\section{FACS analysis}

Anti-human monoclonal antibodies against CD19 (PC5, J3-119, IgG1) and CD27 (PE, 1A4, IgG1), obtained by Immunotech (Marseille Cedex, France) were used. For flow cytometry $50 \mu \mathrm{l}$ cell suspension $\left(2 \times 10^{6} / \mathrm{ml}\right)$ of isolated $B$ cells and either $B$ cells, which did migrate to rhCXCL13 or LNB CSF, and those that have not migrated were incubated with $5 \mu \mathrm{l}$ of CD19 and $10 \mu \mathrm{l}$ of CD27 each for 15 minutes at room temperature in the dark. $1 \mathrm{ml}$ PeliLyse lysing reagent (Hiss Diagnostics GmbH, Freiburg, Germany) was added to each of the tubes and incubated for another 10 minutes in the dark at room temperature. The cells were washed and resuspended in $200 \mu \mathrm{l}$ PBS (Merck KGaA, Darmstadt, Germany) and afterwards immediately analysed.

Analysis was performed on a FACS Canto II flow cytometer (Becton Dickinson, San Jose, USA) using FACSDiva software. 10,000 events were acquired. Data were displayed as two colour plots (CD19/CD27). The data of migrated $\mathrm{B}$ cells were compared with those of non migrated B cells.

\section{ELISA}

From the CSF/serum samples used for the migration assays, sufficient volume for the quantitative measurement of the chemokines CXCL12, CCL19 and CCL21 was available from 12 NIND (mean cell count $1.89 / \mu \mathrm{l}$, mean total CSF protein $553 \mathrm{mg} / \mathrm{l}$, mean age 65.2 years, and $58 \%$ male), $14 \mathrm{NB}$ (mean cell count 375.6/ $\mu$ l, CSF protein $1,186 \mathrm{mg} / \mathrm{l}$, mean age 56.4 years, and $64 \%$ male) and all NS patients. CXCL13 levels in CSF and serum samples were measured in all samples used in the migration assays. A part of the samples have already been analysed for CXCL13 before $[10,16]$. The measurements were done by ELISA (R\&D) according to the recommendations of the manufacturer.

\section{Inhibition assay}

To investigate the chemotactic impact of CXCL13, CXCL12 and CCL19 on the human B cells, the respective chemokines in the CSF samples from LNB patients were blocked with neutralizing antibodies. For the isolated blockade of CXCL13 activity, $10 \mu \mathrm{g} / \mathrm{ml}$ of the neutralizing polyclonal CXCL13 antibody or an isotype control anti- body $(10 \mu \mathrm{g} / \mathrm{ml})$ (all $\mathrm{R} \& D$ ) was used. For triple inhibition assays, we added additional $10 \mu \mathrm{g} / \mathrm{ml}$ polyclonal CCL19 and $50 \mu \mathrm{g} / \mathrm{ml}$ polyclonal CXCL12 antibody or analogous amounts of isotype control antibodies. In pre-tests, we could show that the CXCL13 and CCL19 antibodies inhibit $>99 \%$ of the chemotactic effect of $50 \mathrm{ng} / \mathrm{ml}$ rhCXCL13 and rhCCL19, respectively. In contrast, though testing several available neutralizing antibodies in different concentrations, the blockade of CXCL12 activity only reached $42 \%$. Cross reactivity between all applied antibodies was tested and not observed. All samples were preincubated on a shaker with the respective antibody for 30 $\mathrm{min}$ at RT. As negative control, we used a mixture from 12 CSF samples from NIND patients as they would represent the baseline of migratory activity in vivo, $500 \mathrm{ng} / \mathrm{ml}$ rhCXCL13 served as positive control. To perform the assay, sufficient CSF volume from 12 patients was available, but only 9 samples were tested as their MI was higher than all NIND samples. In addition, 3 LNB CSF samples were either heated at $60^{\circ} \mathrm{C}$ for 10 minutes to denature protein structures, filtrated for $90 \mathrm{~min}$ at $14 \mathrm{~g}$ using a membrane with a $3 \mathrm{kDa}$ Nominal Molecular Weight Limit (Millipore), or the B cells were preincubated for $90 \mathrm{~min}$ with $5 \mu \mathrm{g} / \mathrm{ml}$ PTx. All experiments were performed in duplicate.

\section{Statistics}

In order to assess statistical significant differences of the chemotactic activity of CSF samples obtained from patients with NIND, LNB, or NS on isolated B cells we used one way analysis of variance (ANOVA) and Bonferroni adjustment. This statistical test was also used to measure the significant differences between the chemokine concentrations of these groups in the ELISA assays. The paired t-test was used to measure the differences in the migration behaviour of B cells between antibody- and isobody-control groups in the inhibition assays. The data were expressed as mean $\pm \mathrm{SD}$.

\section{Results \\ Chemotactic activity of CXCLI 3 and CSF from LNB patients on $B$ cells}

First, we determined the chemotactic impact of recombinant human (rh)CXCL13 on human B cells in a well established chemotaxis assay, the modified boyden chamber $[19,20]$. rhCXCL13 had a dose-dependent chemotactic activity by increasing the amount of migrating B cells between 1.5-fold (at $5 \mathrm{ng} / \mathrm{ml}$ ) and 7.4-fold (at $500 \mathrm{ng} / \mathrm{ml}$ ) in comparison to the medium control (data not shown). The proportion of mature, CD27+ B cells was $73.9 \%$ in the migrated cells, while only $25.5 \%$ of the non-migrated cells were expressing this activation marker (Fig. 1d).

Next, we analysed the migratory activity of CSF samples from different patient groups (NIND, LNB, and NS) on B cells. The migratory index (MI, for details please refer to 

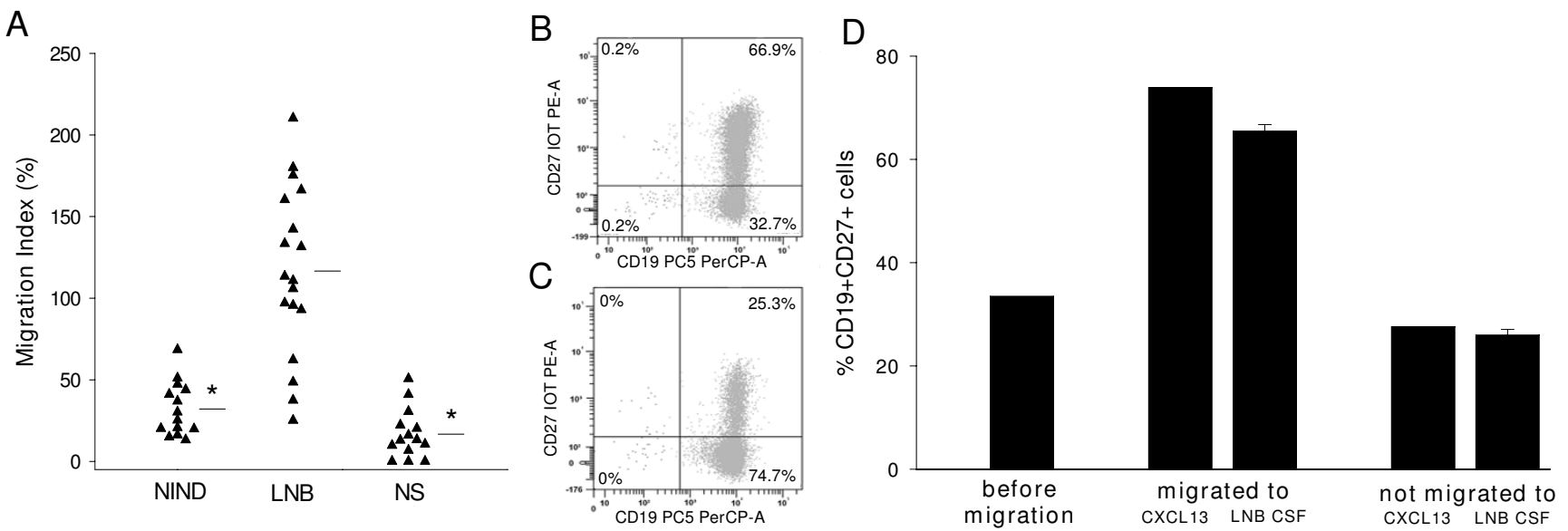

Figure I

Migration of B cells to CSF samples. (A) migration index of CDI9+ B cells to CSF samples from different patient groups, horizontal bars represent the mean value, *: $p<0.00 \mathrm{I}$. (B) and (C) exemplary result of a FACS analysis of (B) migrated or (C) not-migrated $\mathrm{CD} 19^{+} \mathrm{CD} 27^{+} \mathrm{B}$ cells towards the CSF sample of a LNB patient. (D) percentage of migrated vs. not-migrated $\mathrm{CD} 27^{+} \mathrm{CD} 19^{+} \mathrm{B}$ cells, using either CSF-samples of patients with LNB $(\mathrm{n}=3)$ or $500 \mathrm{ng} / \mathrm{ml} \mathrm{rhCXCLI3}$ (mean of two independent experiments, done in duplicate) as chemotactic agents.

the Methods section), was clearly higher for the LNB group (MI = 116) than for both other patient groups (32.1 for NIND and 16.8 for NS, p < 0.001) (Fig. 1a). Similar to rhCXCL13, $65.5 \%$ of the $\mathrm{B}$ cells that have migrated towards the CSF of LNB patients were expressing CD27, in contrast to $26 \%$ of the non-migrating cells (Fig. 1b-d). Together, these findings indicate, that predominantly mature, activated B cells are attracted by both, rhCXCL13 (in concentrations as found in the CSF of LNB patients) and the CSF of LNB patients.

\section{Concentration of B cell-attracting chemokines in CSFI serum sample-pairs}

To identify the immune factors responsible for the increased chemotactic activity of CSF samples from LNB patients, we measured the concentration of the four major B cell attracting chemokines CXCL13, CCL19, CXCL12 and CCL21 in CSF samples from all three patient groups (LNB, NIND and NS). The concentration of CXCL13 was significantly increased in the CSF of LNB patients (mean $=7,864 \mathrm{pg} / \mathrm{ml}$, range 209-26,769) compared to NIND (25 $\mathrm{pg} / \mathrm{ml}, 0-188)$ and NS patients $(426 \mathrm{pg} / \mathrm{ml}, 0-750$, Fig. 2a). A significant higher level in LNB patients than in both other patient groups was also found for CCL19 (400 pg/ $\mathrm{ml}, 72-959$ vs. $52 \mathrm{pg} / \mathrm{ml}, 21-107 \mathrm{in} \mathrm{NIND}$ and $104 \mathrm{pg} / \mathrm{ml}$, 42-176 in NS patients, Fig. 2d). For CXCL12, the difference was significant between LNB $(1,797 \mathrm{pg} / \mathrm{ml}, 404$ $3,963)$ and NIND (564 pg/ml, 0-938), but not NS (1,239 $\mathrm{pg} / \mathrm{ml}, 759-1,818$, Fig. $2 \mathrm{~g})$. For CCL21 (1 pg/ml, 0-13 in LNB vs. $17 \mathrm{pg} / \mathrm{ml}, 0-140$ in NIND and $12 \mathrm{pg} / \mathrm{ml}, 0-75$ in NS) no significant difference between the patient groups was observed. These findings argue for a role of CXCL13, CCL19, and CXCL12, but not CCL21 for B cell recruitment in LNB.

As a chemotactic gradient is a major determinant of chemotactic activity, the concentration of each chemokine was also measured in the corresponding serum samples (Fig. $2 \mathrm{~b}, \mathrm{e}$, and $2 \mathrm{~h}$ ) and the CSF-to-serum ratio (CSR) was calculated. While an increased CSR in LNB was detected for CCL19 (CSR $=5$, Fig. 2f) and a marginal difference was found for CXCL12 (CSR = 1.1, Fig. 2i), the most impressive gradient, 28.6 fold higher than that of CCL19, was found for CXCL13 (CSR = 143, Fig. 2c). In a next step, the CSR of the three chemokines was plotted with the MI of the respective CSF samples. As visualized in Fig. 3, the CSR of both, CXCL13 and CCL19, but not CXCL12 was found to be associated with an elevated MI. Combining the high chemotactic gradient and its association with the MI, CXCL13 appears to be the major candidate for a functional role in B cell recruitment to the CSF in LNB.

\section{Blocking the migration with neutralizing chemokine antibodies}

The functional role of the $\mathrm{B}$ cell attracting chemokines was further analysed using neutralizing antibodies. CSF samples of LNB patients were preincubated with either a neutralizing CXCL13-antibody alone or all three (CCL19, CXCL12 and CXCL13) antibodies together. Compared with the isotype controls, blocking the CXCL13 activity alone reduces the percentage of migrated cells up to $56 \%$ (mean 36.2\%, p =0.005) (Fig. 4a). In more than 50\% of 

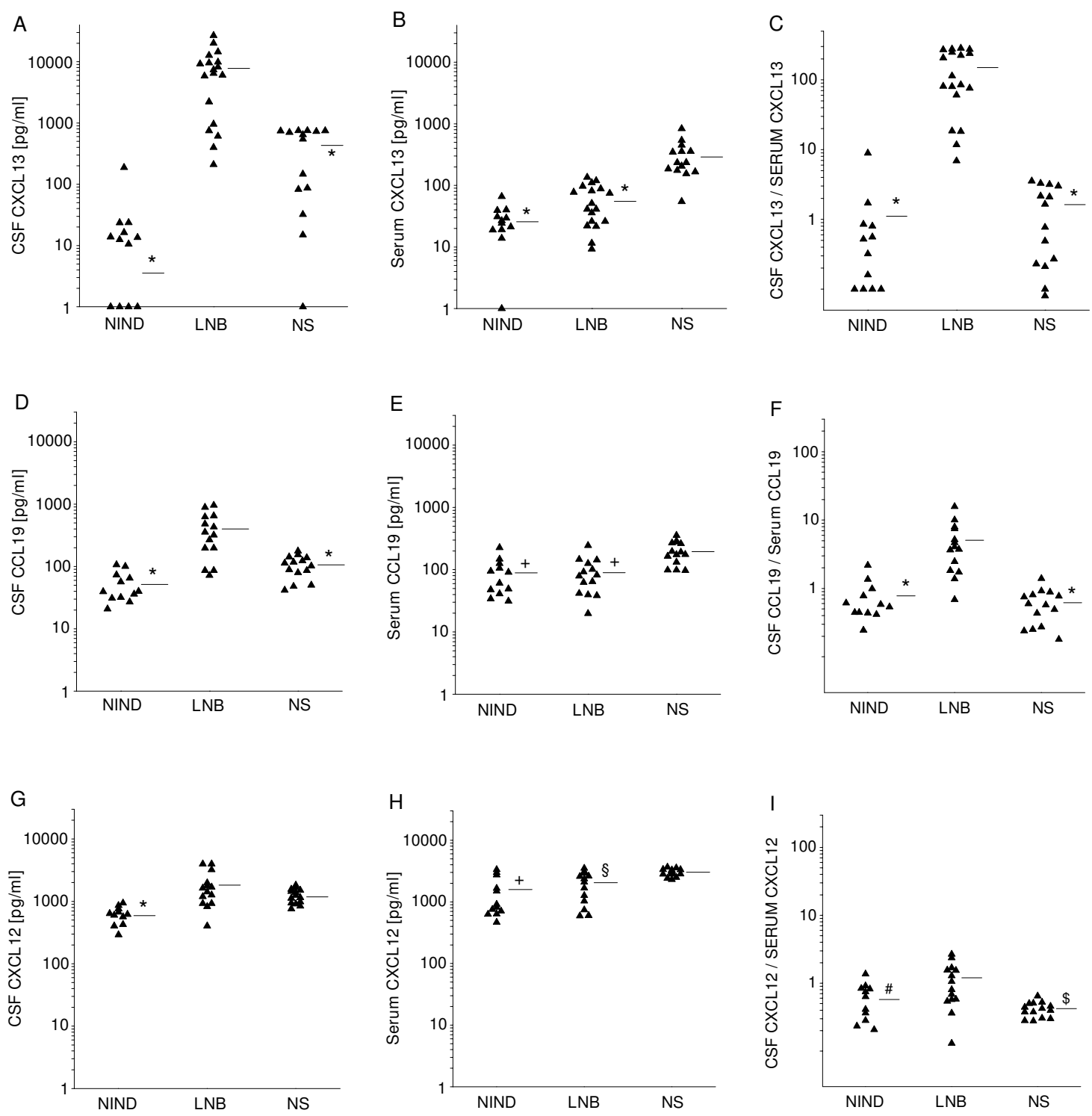

Figure 2

Concentration of Chemokines in CSF samples. Concentration of the respective chemokines in either CSF- (A, D, and $\mathrm{G})$ or serum-samples $(\mathrm{B}, \mathrm{E}$, and $\mathrm{H})$ of the different patient groups, and accordingly the calculated CSF-to-serum ratio (C, F, and I), horizontal bars represent the mean value, *: $p<0.001, \$: p=0.003$, and \#: $p=0.021$ vs. LNB, and +: $p<0.001$, and $\S p=$ 0.013 vs. NS

the samples, the addition of CCL19 and CXCL12 did not further substantially decrease the migratory activity. However, in patient Nr. 3, neutralizing CXCL13 alone had hardly any effect, while all three antibodies together reduced the migration by nearly 50\%. Therefore, the CCL19- and CXCL12- antibodies were also separately tested in this sample, and the neutralizing capacity of the CCL19-antibody was more than 2-fold higher than that of the CXCL12 antibody (Fig. 4b). Taken together, the inhibition assays show that CXCL13 seems to play the domi- nant functional role for B cell migration to LNB CSF, but both CCL19 and CXCL12 might contribute in selected samples.

\section{Additional, yet unidentified chemotactic factors may also} be involved

Although our results suggest that CXCL13 is a key determinant of chemotactic activity for B cells in LNB, additional factors appear to be involved as the inhibition has not been complete. To get a first insight into further 

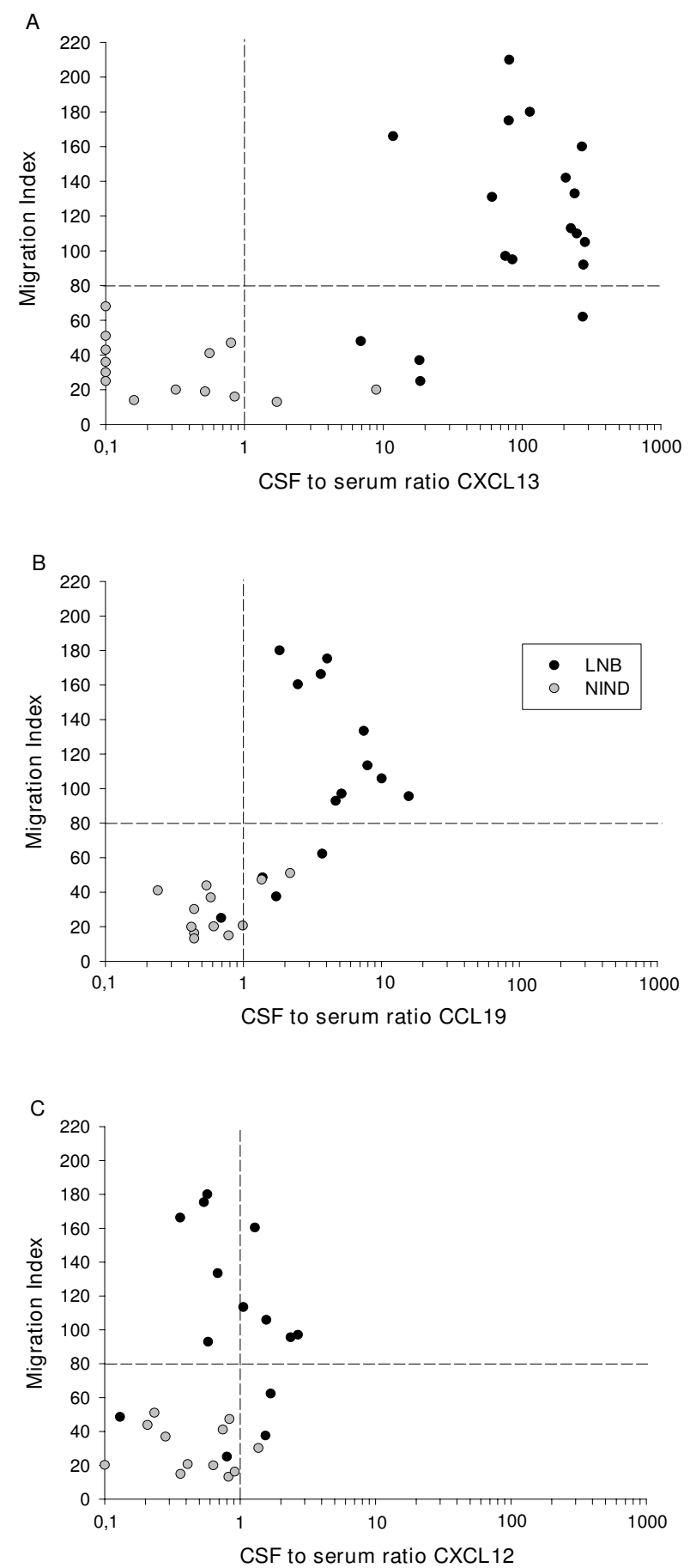

\section{Figure 3}

Correlation of the CSF-to-serum ratio of chemokines with the migration index. Correlation of the CSR of the different chemokines with the MI of the respective CSF sample as measured in the migration assay. A cut-off for the MI was set at 80 , as all CSF samples from NIND patients (and accordingly no inflammatory cell infiltrate in the CSF) had a MI below this value (horizontal dotted line). The vertical dotted line separates the samples with a "negative" CSR $(<1)$ from those with a "positive" CSR (>I). A high proportion of CSF samples in the upper right or lower left quadrant indicate a positive association. 

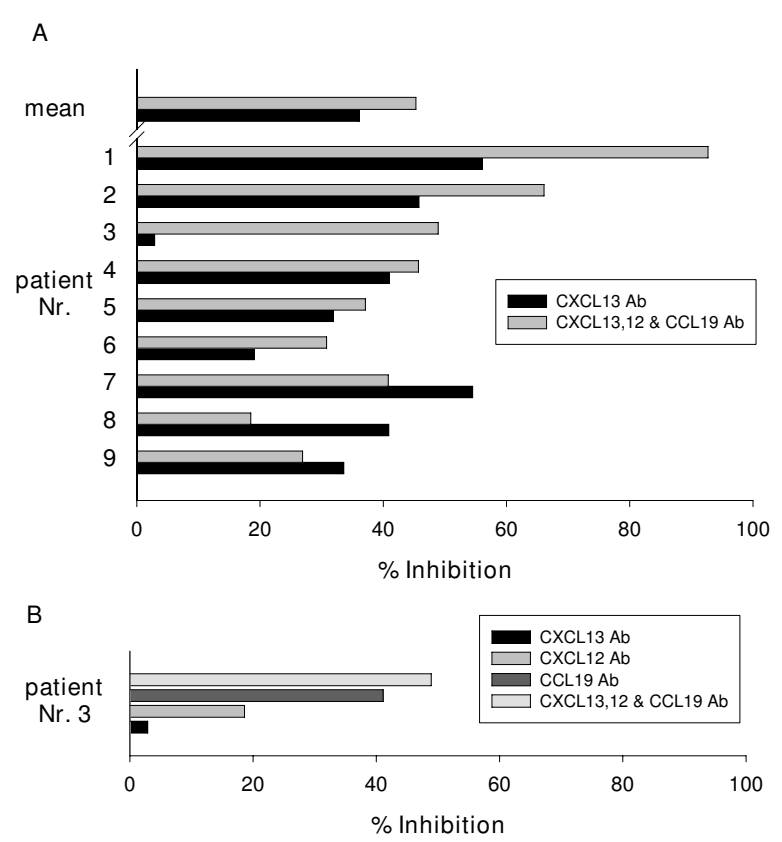

\section{Figure 4}

Inhibition of migration with neutralizing antibodies. (A) Inhibition of the chemotactic effect of CSF samples from 9 LNB patients (same enumeration as in table I) with the indicated antibody (in \% compared with the respective isotype control). (B) All antibodies were used separately in patient $\mathrm{Nr}$. 3, where the CXCLI3 antibody alone had no relevant effect.

immune factors involved, we either filtered the CSF samples to eliminate components with more than $3 \mathrm{kDa}$, denaturized proteins by heating the samples at $60^{\circ} \mathrm{C}$ or preincubated the $\mathrm{B}$-cells with Bordetella pertussis toxin (PTx) to exclude signalling via $\mathrm{G}_{\mathrm{i}}$-proteins (as used by the chemokines [21]). While PTx treatment and heating reduced the migratory activity by approximately $80 \%$, the filtration of components larger than $3 \mathrm{kDa}$ completely eliminated the chemotactic effect. This pattern was similar, if rhCXCL13 was used as chemotactic agent (Fig. 5). Taken together, these yet unidentified chemotactic factors have to be larger than $3 \mathrm{kDa}$, are predominantly heat sensitive and signal via $\mathrm{G}_{\mathrm{i}}$-proteins.

\section{Discussion}

The mechanisms underlying the $\mathrm{B}$ cell rich CSF pleocytosis in LNB are still undefined. Here we demonstrate that CSF of LNB patients is chemotactic to peripheral blood human B cells, and that CXCL13 is a major regulator of B cell recruitment in acute LNB.

The cells that migrated towards the CSF of LNB patients in our in vitro setting were predominantly CD $27+\mathrm{B}$ cells. The surface marker CD $27^{+}$on B cells indicates, that these cells are activated and can produce 5- to 100-fold more immunoglobulins than CD27- cells [22]. Earlier studies on the immune response during the course of B.b. meningoradiculitis revealed, that large numbers of $B$ cells in the CSF and a prominent intrathecal production of antigens are characteristic for LNB [13], suggesting that these Bcells are from the $\left(\mathrm{CD} 27^{+}\right)$mature type. The exact rate of CD27+ cells in the CSF in LNB, however, has not been determined so far. Results from patients with other neuroinflammatory disorders like multiple sclerosis, viral infections, or neurosyphilis showed that $85 \%$ of the total $\mathrm{B}$ cell population in the $\mathrm{CSF}$ are $\mathrm{CD} 27^{+}$, in contrast to $31 \%$ in the peripheral blood [23]. Taken these studies together, $\mathrm{CD} 27+\mathrm{B}$ cells appear to be the main migrating $\mathrm{B}$ cell population in neuroinflammation, both in vivo and in our in vitro experimental setup. Therefore, our in vitro model seems to be a suitable tool to search for the responsible chemotactic agent for B cell immigration in LNB.

This chemotactic agent should fulfil four criteria: a) it has to attract B cells, b) it has to be elevated in the CSF of LNB patients and there must be a gradient over the blood-CSF barrier, c) there should be an association between the gradient and the intensity of B-cell-migration, and d) its neutralization should abrogate the observed $\mathrm{B}$ cell migration to LNB CSF. The four known major B cell attracting chemokines are CCL19, CCL21, CXCL12, and CXCL13, as shown by Brandes et al. [14]. From recent studies, it is known that CXCL13 is elevated in the CSF, but not the blood of LNB patients $[10,16]$. In the current study, we further showed that rhCXCL13, when used in concentrations as found in LNB CSF samples, is chemotactic to B cells. Data concerning the concentration of other B-cell attracting chemokines in LNB CSF are rarely found in the literature. Only CXCL12 was explicitly measured in a small collective of $6 \mathrm{LNB}$ patients with a mean of $24.1 \mathrm{ng} /$ $\mathrm{ml}$ in the CSF of LNB patients and $5.5 \mathrm{ng} / \mathrm{ml}$ in NIND patients $[24,25]$. Elevated levels of CCL19 in the CSF of patients with various infectious diseases (including LNB patients) were determined by two study groups [26,27] with a mean value between $173-250 \mathrm{pg} / \mathrm{ml}$ compared to $26-62 \mathrm{pg} / \mathrm{ml}$ in NIND patients. CCL21 in contrast was not found at measurable concentrations in any of these studies. Exact data for LNB patients or serum concentrations to calculate the gradient of CCL19 or CCL21 were not available. Therefore, we measured the concentrations of CCL19, CCL21, CXCL12 and CXCL13 in CSF/serum pairs of patients with LNB. The most prominent results were found as expected for CXCL13 $[10,16]$ with a more than 300 fold difference in the CSF between LNB and NIND patients and a mean CSR of approximately 150.

All of the LNB patients had not been treated with antibiotics before the lumbar puncture. One of the NS patients 


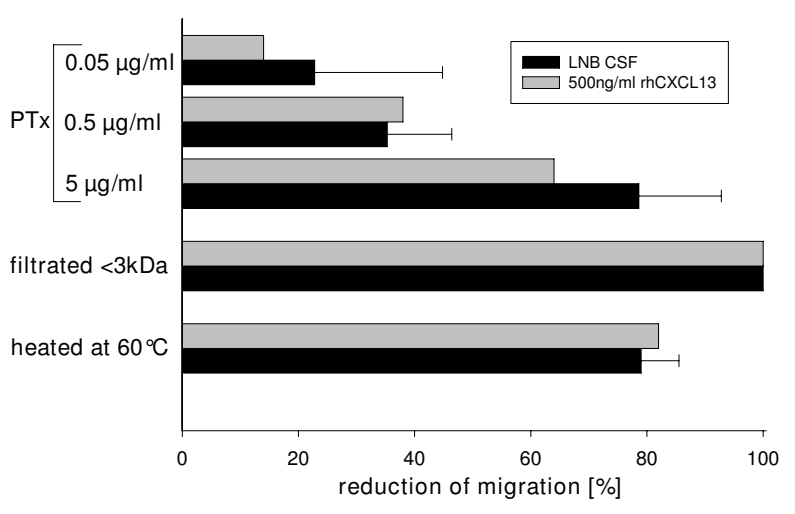

Figure 5

Inhibition of migration with PTx, heating, or filtration of substances $>\mathbf{3} \mathbf{~ k D a}$. CSF samples of LNB patients ( $\mathrm{n}=3$, black bars) or $500 \mathrm{ng} / \mathrm{ml} \mathrm{rhCXCLI} 3$ (mean of two independent experiments, done in duplicates, gray bars) were used as chemotactic agent. Either, the B-cells were preincubated with PTx, or the chemotactic agent was either filtrated to eliminate substances larger than $3 \mathrm{kDa}$ or heated at $60^{\circ} \mathrm{C}$ prior to the migration assay. The reduction of migration was compared to the untreated $B$ cells, or the untreated chemotactic agents, respectively.

received an antibiotic therapy for two weeks before CSF sampling and showed the lowest CXCL13 CSF value of all NS patients. This observation fits perfectly to recent studies demonstrating that (I) viable spirochetes are needed for the production of CXCL13 in monocytic cells [16] and (II) CSF CXCL13 concentrations rapidly decreases under antibiotic therapy in LNB patients [10].

The difference between the patient groups is less impressive for CCL19 but still compatible with a functional chemotactic role: The mean CSF concentration is 8 fold higher than in NIND patients and the mean CSR equals 5.

The results obtained for CXCL12 are lower than those from Pashenkov et al. [24], but the high constitutive expression of CXCL12 in the CNS and the lack of an elevated CSR, arguing against a functional role for B cell immigration, was confirmed in our study. The concentration of CCL21 in the CSF, as expected from previous studies, is hardly measurable in any patient group and a functional role therefore very unlikely. In view of these results, CXCL13, but also CCL19 and less likely CXCL12 were identified as putative chemotactic agents in LNB. This was further underlined by the association analysis. High CXCL13 and CCL19, but not CXCL12 concentrations in LNB CSF were associated with a high MI. Finally, the neutralization experiments underlined the key role of CXCL13, since preincubation with anti-CXCL13 antibod- ies significantly reduced the migration activity of B cells. Therefore CXCL13 fulfils all criteria as stated above.

CCL19 instead, which signals via the CCR7 receptor, appears to play a functional role for B-cells only in single cases (as seen in patient Nr. 3, Fig. 4). However, this chemokine could be important for the immigration of $\mathrm{T}$ lymphocytes instead, as suggested in the literature. Activated T-lymphocytes strongly upregulate CCR7 and efficiently migrate to CCL19 [28], and T-lymphocytes found in the CSF of patients with (not further specified) inflammatory CNS-diseases are CCR7 positive [27]. As CCL19 is much stronger chemotactic for $\mathrm{T}$ than for $\mathrm{B}$ cells, its role in LNB could be the attraction of T cells, but this would have to be determined in further studies.

For the association analysis as shown in Figure 3, the cutoff for an increased migration index was set at 80 , as the CSF of all NIND-patients had a migration below this value. As seen in Figure 3A and 3B and also in Figure 1A, there are four CSF samples from LNB patient with a migration index below 80 . The one of them with the highest MI also has a high CSR for CXCL13 and resembles in its basic CSF findings the other LNB patients (cell count $368 / \mu \mathrm{l}$, albumin CSF/serum quotient 19.1). The three others, however, appear to be a distinct group. They are combining a low CSR for both CXCL13 (7-18.5) and CCL19 (0.71.7) with a low migration index. Compared to the remaining LNB patients, they also have a lower cell count $(19 \pm$ 10 vs. $146 \pm 152$ cells $/ \mu \mathrm{l}, \mathrm{p}<0.01)$, albumin CSF/serum quotient $(7.2 \pm 5.2$ vs. $19.6 \pm 13, \mathrm{p}=0.02)$, and in none of them, plasma cells are found in the CSF (in contrast to a mean of $5 \%$ in the other LNB patients, $\mathrm{p}<0.01$.). Although these data should be interpreted with caution, given the small sample size of this subgroup, the observation that in all three patients low-grade inflammatory CSF changes were paralleled by very low CSRs for CXCL13 and CCL19 (as compared to other LNB patients) further underlines the functional role of both chemokines. It also has to be mentioned that the less pronounced CSF alterations in this LNB subgroup are not reflected by less (or different) clinical symptoms or by clear differences in age or gender. However, we are not aware of the duration between the onset of symptoms and lumbar puncture. Both the quantity and quality of CSF abnormalities (e.g. CSF pleocytosis and CSF chemokine levels) may change over time after infection, which may be an interesting topic to be addressed in future studies.

As the inhibition of CXCL13, CCL19 and CXCL12 does not completely abrogate the chemotactic activity of LNB CSF samples, additional factors have to be involved. In a study by Dubois et al., the supernatant of cultured dendritic cells was found to be chemotactic for B cells [29]. As the supernatant was insensitive to PTx treatment, the 
authors stated that the relevant factors have to be different from classical chemoattractants. In our study, however, the chemotactic activity of both, rhCXCL13 and LNB CSF was reduced by around $80 \%$ by interfering with the PTx pathway, and also heat treatment. In addition, the chemotactic activity of LNB CSF samples and rhCXCL13 was completely blocked by eliminating all substances larger than $3 \mathrm{kDa}$. Chemokines weigh between 6 and $14 \mathrm{kDa}$ [30], signal predominantly via the PTx-sensitive pathway [31], and are as proteins heat sensitive. This indicates that, besides CXCL13, another "similar" chemokine could be responsible for the remaining chemotactic activity after blockade of CXCL13. Another possible candidate could be the complement, as the size of complement factors ranges from 24 to $410 \mathrm{kDa}$, they are heat sensitive and - as shown for C5a - signal via PTx-sensitive G proteins [32]. In addition, it has been demonstrated, that B.b. can induce the production of complement in vitro and in vivo $[33,34]$ and that B cells respond chemotactic to C5a [35]. However, there are even more substances to be considered: components of the Borrelia themselves could also contribute to the chemotaxis. In a study by Benach et al., large proteins of the borrelial membrane like the Outer surface protein A or flagellin had a chemotactic effect on leucocytes [36]. Taken together, further studies are warranted to identify all factors involved in B cell attraction.

\section{Conclusions}

In summary, CXCL13 plays a key role for the immigration of B cells into the CSF in LNB. Therefore - apart from its unquestioned role in dictating homing and motility of lymphocytes in lymphoid tissues [37] - this potent B cell attracting chemokine appears to be also important for attracting B cells to sites of acute bacterial infection.

\section{Competing interests}

The authors declare that they have no competing interests.

\section{Authors' contributions}

TAR and UK have conceived of the study, TAR has established the experimental setting and written the manuscript, AP has carried out most of the experiments, MA has done the FACS analysis, MW and SK have collected the CSF and serum samples, CS and MK have participated in the design of the study and the statistical analysis and helped drafting the manuscript. HWP and UK have participated in the design and coordination of the study and helped to draft the manuscript. All authors read and approved the final manuscript.

\section{Acknowledgements}

We thank B. Angele for technical assistance. This study was supported by grants from the Else-Kröner-Fresenius Stiftung and the Friedrich-Baur Stiftung to T. A. Rupprecht.

\section{References}

I. Legler DF, Loetscher M, Roos RS, Clark-Lewis I, Baggiolini M, Moser $B$ : B cell-attracting chemokine I, a human $C X C$ chemokine expressed in lymphoid tissues, selectively attracts B lymphocytes via BLRI/CXCR5. J Exp Med 1998, I 87:655-660.

2. Cyster JG, Ansel KM, Reif K, Ekland EH, Hyman PL, Tang HL, Luther $\mathrm{SA}, \mathrm{Ngo}$ VN: Follicular stromal cells and lymphocyte homing to follicles. Immunol Rev 2000, 176:181-193.

3. Luther SA, Ansel KM, Cyster JG: Overlapping roles of CXCLI3, interleukin 7 receptor alpha, and CCR7 ligands in lymph node development. J Exp Med 2003, I 97:। I91-II98.

4. Ansel KM, Ngo VN, Hyman PL, Luther SA, Forster R, Sedgwick JD, Browning JL, Lipp M, Cyster JG: A chemokine-driven positive feedback loop organizes lymphoid follicles. Nature 2000, 406:309-3।4.

5. Krumbholz M, Theil D, Cepok S, Hemmer B, Kivisakk P, Ransohoff RM, Hofbauer M, Farina C, Derfuss T, Hartle C, et al:: Chemokines in multiple sclerosis: CXCLI 2 and CXCLI 3 up-regulation is differentially linked to CNS immune cell recruitment. Brain 2006, I29:200-2II.

6. Weyand CM, Goronzy J]: Ectopic germinal center formation in rheumatoid synovitis. Ann N Y Acad Sci 2003, 987:|40-|49.

7. Galamb O, Gyorffy B, Sipos F, Dinya E, Krenacs T, Berczi L, Szoke D, Spisak S, Solymosi N, Nemeth AM, et al.: Helicobacter pylori and antrum erosion-specific gene expression patterns: the discriminative role of CXCLI3 and VCAMI transcripts. Helicobacter 2008, 13:1 12-126.

8. Kahnert A, Hopken UE, Stein M, Bandermann S, Lipp M, Kaufmann $\mathrm{SH}$ : Mycobacterium tuberculosis triggers formation of lymphoid structure in murine lungs. J Infect Dis 2007, 195:46-54.

9. Vermi W, Facchetti F, Riboldi E, Heine H, Scutera S, Stornello S, Ravarino $D$, Cappello $P$, Giovarelli M, Badolato R, et al.: Role of dendritic cell-derived CXCLI3 in the pathogenesis of Bartonella henselae B-rich granuloma. Blood 2006, 107:454-462.

10. Rupprecht TA, Pfister HW, Angele B, Kastenbauer S, Wilske B, Koedel U: The chemokine CXCLI3 (BLC): A putative diagnostic marker for neuroborreliosis. Neurology 2005, 65:448-450.

II. Narayan K, Dail D, Li L, Cadavid D, Amrute S, Fitzgerald-Bocarsly P, Pachner AR: The nervous system as ectopic germinal center: CXCLI3 and IgG in lyme neuroborreliosis. Ann Neurol 2005, 57:813-823.

12. Rupprecht TA, Koedel U, Fingerle V, Pfister HW: The pathogenesis of lyme neuroborreliosis: from infection to inflammation. Mol Med 2008, I 4:205-2I2.

13. Cepok S, Zhou D, Vogel F, Rosche B, Grummel V, Sommer N, Hemmer $B$ : The immune response at onset and during recovery from Borrelia burgdorferi meningoradiculitis. Arch Neurol 2003, 60:849-855.

14. Brandes M, Legler DF, Spoerri B, Schaerli P, Moser B: Activationdependent modulation of $B$ lymphocyte migration to chemokines. Int Immunol 2000, I 2: I 285- I 292.

15. Rupprecht TA, Koedel U, Angele B, Fingerle V, Pfister HW: [Cytokine CXCLI3 - a possible early CSF marker for neuroborreliosis.]. Nervenarzt 2006, 77:470-473.

16. Rupprecht TA, Kirschning CJ, Popp B, Kastenbauer S, Fingerle V, Pfister HW, Koedel U: Borrelia garinii induces $\mathbf{C X C L I 3}$ production in human monocytes through Toll-like receptor 2. Infect Immun 2007, 75:435 I -4356.

17. Ramesh G, Borda JT, Gill A, Ribka EP, Morici LA, Mottram P, Martin DS, Jacobs MB, Didier PJ, Philipp MT: Possible role of glial cells in the onset and progression of Lyme neuroborreliosis. J Neuroinflammation 2009, 6:23.

18. Marra CM, Maxwell CL, Smith SL, Lukehart SA, Rompalo AM, Eaton M, Stoner BP, Augenbraun M, Barker DE, Corbett JJ, et al.: Cerebrospinal fluid abnormalities in patients with syphilis: association with clinical and laboratory features. J Infect Dis 2004, I 89:369-376.

19. Koedel U, Kohleisen B, Sporer B, Lahrtz F, Ovod V, Fontana A, Erfle V, Pfister HW: HIV type I Nef protein is a viral factor for leukocyte recruitment into the central nervous system. J Immunol 1999, I 63: I237-1245.

20. Rupprecht TA, Koedel U, Muhlberger B, Wilske B, Fontana A, Pfister HW: CXCLII is involved in leucocyte recruitment to the central nervous system in neuroborreliosis. J Neurol 2005, 252:820-823. 
21. Amara A, Gall SL, Schwartz O, Salamero J, Montes M, Loetscher P, Baggiolini M, Virelizier JL, renzana-Seisdedos F: HIV coreceptor downregulation as antiviral principle: SDF-I alpha-dependent internalization of the chemokine receptor CXCR4 contributes to inhibition of HIV replication. J Exp Med 1997, 186:139-146.

22. Klein U, Rajewsky K, Kuppers R: Human immunoglobulin (Ig)M+IgD+ peripheral blood B cells expressing the CD27 cell surface antigen carry somatically mutated variable region genes: CD27 as a general marker for somatically mutated (memory) B cells. J Exp Med 1998, 188:1679-1689.

23. Cepok S, von GG, Grummel V, Hochgesand S, Celik H, Hartung H, Hemmer B: Accumulation of class switched IgD-IgM- memory $B$ cells in the cerebrospinal fluid during neuroinflammation. J Neuroimmunol 2006, I 80:33-39.

24. Pashenkov M, Teleshova N, Kouwenhoven M, Smirnova T, Jin YP, Kostulas $\mathrm{V}$, Huang YM, Pinegin B, Boiko A, Link $\mathrm{H}$ : Recruitment of dendritic cells to the cerebrospinal fluid in bacterial neuroinfections. J Neuroimmunol 2002, I22:106-116.

25. Li M, Ransohoff RM: Multiple roles of chemokine CXCLI 2 in the central nervous system: a migration from immunology to neurobiology. Prog Neurobiol 2008, 84: I |6-I3I.

26. Krumbholz M, Theil D, Steinmeyer F, Cepok S, Hemmer B, Hofbauer $M$, Farina C, Derfuss T, Junker A, Arzberger T, et al.: CCLI 9 is constitutively expressed in the CNS, up-regulated in neuroinflammation, active and also inactive multiple sclerosis lesions. J Neuroimmunol 2007, 190:72-79.

27. Giunti D, Borsellino G, Benelli R, Marchese M, Capello E, Valle MT, Pedemonte E, Noonan D, Albini A, Bernardi G, et al.: Phenotypic and functional analysis of $T$ cells homing into the CSF of subjects with inflammatory diseases of the CNS. I Leukoc Biol 2003, 73:584-590.

28. Nagira M, Imai T, Yoshida R, Takagi S, Iwasaki M, Baba M, Tabira Y, Akagi J, Nomiyama $H$, Yoshie O: A lymphocyte-specific CC chemokine, secondary lymphoid tissue chemokine (SLC), is a highly efficient chemoattractant for $B$ cells and activated $T$ cells. Eur J Immunol 1998, 28:1516-1523.

29. Dubois B, Massacrier C, Caux C: Selective attraction of naive and memory B cells by dendritic cells. J Leukoc Biol 200I, 70:633-64I.

30. Kim CH, Broxmeyer HE: Chemokines: signal lamps for trafficking of $\mathrm{T}$ and $\mathrm{B}$ cells for development and effector function. J Leukoc Biol 1999, 65:6-15.

31. Olson TS, Ley K: Chemokines and chemokine receptors in leukocyte trafficking. Am J Physiol Regul Integr Comp Physiol 2002, 283:R7-28.

32. Teixeira MM, Giembycz MA, Lindsay MA, Hellewell PG: Pertussis toxin shows distinct early signalling events in platelet-activating factor-, leukotriene B4-, and C5a-induced eosinophil homotypic aggregation in vitro and recruitment in vivo. Blood 1997, 89:4566-4573.

33. Kochi SK, Johnson RC: Role of immunoglobulin G in killing of Borrelia burgdorferi by the classical complement pathway. Infect Immun 1988, 56:3।4-32I.

34. Henningsson AJ, Ernerudh J, Sandholm K, Carlsson SA, Granlund H, Jansson C, Nyman D, Forsberg P, Nilsson EK: Complement activation in Lyme neuroborreliosis--increased levels of $\mathrm{Clq}$ and $\mathrm{C} 3 \mathrm{a}$ in cerebrospinal fluid indicate complement activation in the CNS. J Neuroimmunol 2007, I 83:200-207.

35. Kupp LI, Kosco MH, Schenkein HA, Tew JG: Chemotaxis of germinal center B cells in response to C5a. Eur J Immunol 1991, 2I:2697-270I.

36. Benach JL, Coleman JL, Garcia-Monco JC, Deponte PC: Biological activity of Borrelia burgdorferi antigens. Ann N Y Acad Sci 1988 , 539:II5-125.

37. Mueller SN, Hosiawa-Meagher KA, Konieczny BT, Sullivan BM, Bachmann MF, Locksley RM, Ahmed R, Matloubian M: Regulation of homeostatic chemokine expression and cell trafficking during immune responses. Science 2007, 3 17:670-674.

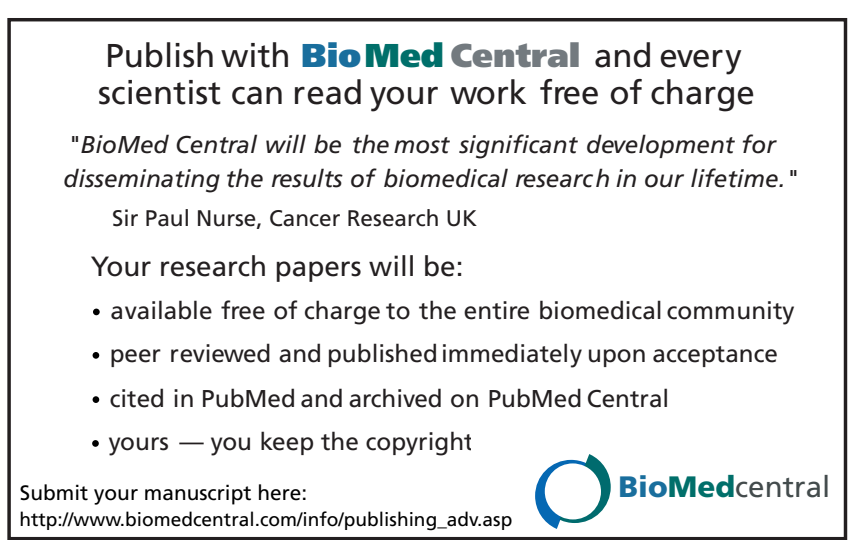

